\title{
ORGANIZATIONAL AGILITY IN HEALTH ORGANIZATIONS: THE ROLE OF VISIONARY LEADERSHIP*
}

\author{
DOI: 10.17261/Pressacademia.2020.1184 \\ RJBM-V.7-ISS.1-2020(2)-p.13-22
}

\section{Elif Ozeroglu ${ }^{1}$, Yesim Kocyigit ${ }^{2}$}

${ }^{1}$ Istanbul Gelisim University, Institute of Social Sciences, Istanbul, Turkey. elifozeroglu@gmail.com, ORCID: 0000-0002-7986-8886

${ }^{2}$ Istanbul Gelisim University, Faculty of Economics, Administrative and Social Sciences, Istanbul, Turkey. yesimkocyigit@gmail.com, ORCID: 0000-0003-2192-8492

Date Received: December 11, 2019

Date Accepted: March 14, 2020

To cite this document

Ozeroglu, E., Kocyigit, Y., (2020). Organizational agility in health organizations: the role of visionary leadership. Research Journal of Business and Management (RJBM), V.7(1), p.13-22.

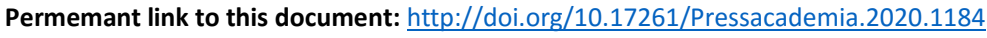

Copyright: Published by PressAcademia and limited licenced re-use rights only.

\section{ABSTRACT}

Purpose- The aim of this study is to determine the effect of visioner leadership on organizational agility in hospitals.

Methodology- In order to measure the research variables, surveys on visioner leadership and organizational agility were used and the staff who have been working in hospitals in Beylikdüzü region replied to survey questions. 199 proper forms of surveys were gained. Simple and multiple regression analyses were done to determine the effect of visionary leadership on organizational agility and the effects of sub dimensions of visionary leadership on the sub dimensions of organizational agility.

Findings- According to the statistical results of the research, visionary leadership behaviors meaningfully affect the organizational agility, and there are also that being open to changes and action oriented which are sub-dimentions of visionary leadership affect the competency dimension of the organizational agility; the action oriented affects both the competency and the speed dimensions of the organizational agility; portrait of the future which is a sub-dimension of the visioner leadership affects the the responsiveness sub-dimension of organizational agility.

Conclusion- The results of the study emphasize the importance of visioner leadership to gain the organizational agility abilities such as responsiveness, competency and speed.

Keywords: Visionary leadership, organizational agility, competency, speed, responsiveness

JEL Codes: M21, M50, M54

\section{HASTANE IŞLETMELERINDE ÖRGÜTSEL ÇEVIKLIK: VIZYONER LIDERLIĞiN ROLÜ}

\section{ÖZET}

Amaç- Bu çalışmanın amacı hastane işletmelerinde vizyoner liderliğin örgütsel çeviklik üzerindeki etkisini belirlemektir.

Metodoloji- Araştırma değişkenlerini ölçmek için vizyoner liderlik ve örgütsel çeviklik anketleri kullanılmış, bu anketlerin i̇stanbul ili Beylikdüzü ilçesindeki özel hastanelerde çalışanlar tarafından doldurulması sağlanmıştır. Analizlerde kullanılabilecek 199 anket elde edilmiştir. Vizyoner liderliğin örgütsel çeviklik üzerindeki etkisini, vizyoner liderliğe ait alt boyutların örgütsel çevikliğe ait alt boyutlar üzerindeki etkilerini tespit etmek üzere basit ve çoklu regresyon analizleri yapılmıştır.

Bulgular- Analizler sonucunda vizyoner liderlik davranışlarının örgütsel çevikliği, vizyoner liderliğin alt boyutlarından değişimlere açık olma ile eylem odaklılığın örgütsel çevikliğin yetkinlik boyutunu; eylem odaklılığın örgütsel çevikliğin hem yetkinlik hem de hız boyutunu; vizyoner liderliğin geleceğin resmi alt boyutunun örgütsel çevikliğin cevap verme alt boyutunu anlamlı olarak etkilediği görülmüştür.

Sonuç- Araştırmanın sonuçları, cevap verme, yetkinlik ve hız gibi örgütsel çeviklik yeteneklerini edinmekte vizyoner liderliğin önemini vurgulamaktadır.

Anahtar Kelimeler: Vizyoner liderlik, örgütsel çeviklik, yetkinlik, hız, cevap verme JEL Kodları: M21, M50, M54

* Bu makale "Vizyoner Liderliğin Örgütsel Çeviklik Üzerine Etkisi; istanbul ili Beylikdüzü Ilçesindeki Özel Hastanelerde Bir Uygulama" başlıkl yüksek lisans tezinden üretilmiştir. 


\section{GíRiş}

Artan küreselleşme, kısıtlamalar, teknolojik yeniliklerin hızlı gerçekleşmesi ve müşteri taleplerindeki değişimler nedeniyle, günümüz işletmeleri için rekabet şiddetlenmiş durumdadır. Böyle bir çevrede faaliyet gösteren tüm işletmeler daha dinamik, daha esnek olmak; çevreye uyum sağlamak için çevik yeteneklere sahip olmak zorundadırlar. Çünkü çevresel koşullar hızlı ve köklü değişimleri gerektirebilmektedir. Örgütsel çeviklik, bir örgütün yaklaşmakta olan bir tehdit veya fırsata zamanında yanıt verebilme veya uyum sağlayabilme yeteneğini ifade etmektedir. Örgütsel çeviklik son yıllarda önem kazanmış ve şirketlerin hayatta kalabilmeleri konusunda büyük bir etkiye sahip olmuştur. Örgütsel çevikliğin alt boyutları olan cevap verme, hız, yetkinlik ve esneklik de sürdürülebilirliğinin yanı sıra, şirketlerin rekabet üstünlüğü kazanabilmeleri, kar paylarını arttırabilmelerine katkı sağlamaktadır.

Liderler, dış çevredeki eğilimleri tespit etmek ve örgütü bu eğilimlere hazırlamakta önemli bir role sahiptir. Graetz (2000)'e göre liderlik, karizmatik ve araçsal olmak üzere iki rolü içermektedir. İki rol birbirinden farklı işlevler gerçekleştirmelerine ragmen, birbirinin güçlendiricisi ve tamamlayıcısıdır. Karizmatik liderlik güçlü bir şekilde kişilerarası ilişkilere dayanmaktadır. Planlama, takipçileri güçlendirme ve enerji vermede çok önemlidir. Araçsal liderliğin önemli unsurları örgütsel tasarım, control ve istenen davranışları motive eden koşulları yaratmak için çevresel yönetimi içeren ödüldür. Vizyoner liderlikte her iki rolün dengili bir şekilde vücut bulduğu ifade edilebilir. Çünkü vizyoner liderler, organizasyonlarını zamanın belirsizliğinden arındırarak, ortak başarıyı özendirerek tüm organizasyonu daha geniş ufuklara yönlendirirler. İşletmeyi başarıya ulaştırabilecek olan yolda geleceğin resmini çalışanlarıyla birlikte hareket ederek oluşturan, onlarla birlikte emek harcayan, yüksek motivasyon oluşturma yeteneği sayesinde çalışanlarını en iyi performans seviyesine çıkaran, güçlü örgüt kültürü oluşturarak bunu örgüt geneline yayan, bütün bunları hayata geçirirken gereken değişim ve gelişimin bilincinde olan kişilerdir.Vizyoner liderlerin bu yetenekleri, çevresel koşulları gözönünde tutarak, örgütün gelecekte ulaşmayı hedeflediği noktaya ulaşabilmesi için yeni strateji ve girişimler uygulamaya elverişli olacak şekilde örgütlerini çevik hale getirebilir düşüncesi, bu çalışmada vizyoner liderlik ve örgütsel çeviklik üzerine odaklanmaya neden olmuştur. Diğer bir ifade ile bu çalışmanın amacı vizyoner liderliğin örgütsel çeviklik üzerine, vizyoner liderliğe ait alt boyutların örgütsel çevikliğe ait alt boyutlar üzerine etkilerini tespit etmektir. Bu amaç için İstanbul ili Beylikdüzü ilçesindeki özel hastanelerde görev yapan doktor, hemşire, sağıı memuru, idari işler memuru ve diğer çalışanlar üzerinde görgül bir çalışma yapılmıştır. Literatürde vizyoner liderlik kavramı ve örgütsel çeviklik arasındaki uyum kapsamlı olarak belirtilse de ülkemizde bu iki konunun incelenmesine yönelik çalışmaya rastlanmamıştır. íki değişken arasındaki bağ konusunda literatüre sağlayacağı katkılara ilave olarak araştırma, yöneticilerin vizyoner liderlik yeteneklerini geliştirmek ve bu sayede işletmelerini daha çevik hale getirerek çevreye uyum sağlamaları konusunda onlara ışık tutacaktır.

Makalenin geri kalanı beş bölümden oluşmaktadır: kavramsal çerçeve oluşturan ve model ile hipotezleri vurgulamak için önceki araştırmaları gözden geçiren bir literatür; akabinde amaç ve hipotezler tanımlanmış; metodoloji bölümünde örneklem ve ölçekler açıklanmış; daha sonra analiz sonuçları sunulmuş ve yorumlanmış; son bölümde ise sonuçlar tartılışılmış ve çıkarımlar yapılmıştır.

\section{LITERATÜR TARAMASI}

Liderlik literatürü incelendiğinde, neredeyse bu kavramı tanımlamaya çalışan kişi sayısı kadar çok liderlik tanımı olduğu görülebilir. Liderlik; özellikler, davranışlar, etki, etkileşim kalıpları, rol ilişkileri ve idari bir pozisyonu işgal etme gibi açılardan tanımlanmıştır. Ayrıca, benzer olguları açıklamak için iktidar, güç, otorite, idare, yönetim, kontrol ve denetim gibi diğer belirsiz terimlerin kullanılması karmaşaya neden olmaktadır. Tanımlarının çoğunda şu varsayım mevcuttur; liderlik, insanlar üzerinde kasıtlı bir etki icra ederek bir gruptaki veya örgütteki faaliyetlere ve ilişkilere yön verme, bunları yapılandırma veya kolaylaştırmayı kapsayan bir süreçtir (Yukl, 2018: 2).

Liderliğin geçmişten beri sahip olduğu cazibesi ve büyüsü, bu alanda yapılan araştırmaların sayısını arttırmış ve konu için geniş bir literatür oluşturmuştur. Literatürdeki çalışmalar bakış açılarına göre sınıflandırıldığında karşımıza üç temel teori çıkmaktadır. Bunlar özellikler teorisi, davranış teorisi ve durumsallık teorisidir.

Özellikler teorisine göre, liderin sahip olduğu özellikler liderlik sürecinin etkinliğini belirlemede en önemli faktör olarak kabul edilir. Başka bir deyişle liderin sahip olduğu özellikler belli bir grup içinde kişinin lider olmasını ve grubu yönetmesini etkilemektedir. Lider, özellikleri itibariyle diğer grup üyelerinden farklı bir kişidir. Bu özellikler boy, ağırlık, güçlülük, yaş, fiziksel olgunluk, sağlık durumu, yakışıklılık gibi fiziksel özellikler; uyum sağlama, özgüven, yaratıcılık, kişisel bütünlük, üstünlük, bağımsızlık, ortama uyum sağlayabilme, ortamın şartlarına duyarlı olabilme, hırslı ve başarıya güdülü, fikrini savunan, işbirliğine yatkın, kararlı, güvenilir, baskın (başkalarını etkileme), ısrarlı, kendine güvenen, zorluklara karşı dirençli, sorumluluk almaya istekli olmak gibi kişisel özellikler ile zeka, bilgi, kesinlik, etkili konuşma becerisine sahip olma, yaratıcı, politik ve diplomatik, konusunda bilgili, planlı ve ikna edici olma gibi yeteneklerden oluşmaktadır. Bu kurama göre insanlar lider olarak doğarlar sonradan lider olamazlar (Koçel, 2001: 400). 
Özellikler teorisi lider etkililiğini açıklamada yetersiz kalınca, 1950'li yıllarda araştırmacılar başka etkenlere yoğunlaşmışlar ve yöneticilerin iş başında neler yaptıklarını incelemişlerdir. Bu çalışmalar neticesinde liderlin davranışlarını esas alarak davranışsal liderlik teorilerini ortaya koymuşlardır. Davranışsal teoriler, liderlik süreci içerisinde lideri diğer grup üyelerinden ayıran özelliğin liderlerin davranışları olduğunu belirtmişlerdir. (Şimşek, 2001: 172). Bu davranışlar da liderin izleyenleri ile iletişim ve amaçları belirleme şekli gibi konuları içermektedir (Tengilimioğlu, 2005).

Özellikler teorisi ve davranışsal liderlik teorilerine getirilen çeşitli eleştiriler ve bu teorilerde ortaya çıkan eksiklikler sonucunda liderlik konusunda daha gerçekçi olan ve içerisinde bulunulan durumun da dikkate alınması gerektiğini öngören bir yaklaşıma intiyaç duyulmuştur. Durumsallık teorisine göre her durumun koşulları, belirleyicileri birbirinden farklıdır. Bu koşullar ve belirleyiciler farklı zamanlarda farklı düzeylerde etkileşime girerek bambaşka sonuçlar doğurabilmektedir. Astların özellikleri, gerçekleştirilecek amaç, kararların önem derecesi ve aciliyet düzeyi, görev ya da ilişki odaklı olma gerekliliği gibi faktörlere bağlı olarak lider davranışları farklılık gösterebilecektir.

Bu geleneksel liderlik yaklaşımlarından sonra, belirsizliklerle dolu ve şiddetli rekabetin olduğu çevrelerde faaliyet göstermeye çalışan örgütlerin dış çevreye uyumunu sağlamak, etkinlik ve verimliliğini arttırarak sürdürülebilirliğini mümkün kılmak amacıyla pek çok modern liderlik yaklaşımı ileri sürülmüştür. Bunlardan biri de vizyoner liderliktir.

Sashkin'in vizyoner liderlik teorisi, yöneticinin vizyonunun içeriği ve vizyonu oluştururken geçen sürecin üzerinde durmaktadır. Sashkin'e göre vizyoner liderlikle ilgili olarak üç ana bölüm vardır. Bunlar; değişim, ideal amaçlar ve sosyal yönlendirmedir. Vizyon, çevredeki değişim ve örgütsel uyum için nelerin gerekli olduğunun ön görülmesini sağlar. Vizyoner liderlik özelliklerinin daha anlaşılabilir kılınması için öncelikle vizyonun önemli noktaları ve anahtar konuları üzerinde durulması devamında ise çift yönlü etkileşim sağlanarak çalışanlara bilginin ve vizyonun aktarılması gerekmektedir. Üçüncü kritik nokta ise vizyoner liderlerin tutarlı ve güvenilir davranışlar sergilemesidir (Zaccaro, 2001: 50). Çınar ve Kaban (2012) vizyoner liderliği dört alt boyut ile ifade etmişlerdir. Bunlar vizyoner düşünce, eylem odaklı olma, geleceğin resmi, değişimlere açık olmadır. Bu boyutların açıklamaları şu şekildedir:

Vizyoner düşünce: Vizyoner lider izlenilecek yolu, ulaşılacak hedefleri tanımlamalı ve vizyonu çalışanlara açık, sözlü ve yazılı iletişim yoluyla aktarmalıdır. Vizyonu farklı koşullarda da uygulanabilir hale getirmek için örgüt faaliyetlerine hakim olmalı, onları önceliklerine göre sıralamalıdır (Robbins, 2000: 245).

Eylem odaklı olma: Vizyoner lider yetki devri yaparak, astlarına birtakım sorumluluklar vererek, planlama sürecine onları da katarak, vizyonu örgüt geneline yayarak çalışanlardan vizyonu sahiplenmelerini sağlayarak beklenenin üstünde performans sağlarlar (Quigley, 1998: 280).

Değişimlere açık olma: Vizyoner liderler, izleyenlerin birbirleriyle ve dünya ile olan ilişkileri sonucu elde ettikleri genel düşünceleri geliştirmelerine yardımcı olan genel durum, sosyal ihtiyaçlar, problemlerin açıklaması ve vizyona yönelik umut verici çözümler hakkında anladıklarını birlikte ortaya koyarlar. Bu vizyon, geçmiş deneyimlerin, bugünkü olanakların, temel değerlerin ve kültürel geleneklerin bir yansımasıdır. Onlar değerlerin gelecekte nasıl anlamlandırılacağını lider ve izleyenlerin davranışları yoluyla gösterirler (Crosby, 1999: 107).

Geleceğin resmi: Vizyoner liderler çalışmalarını kurumu geleceğe hazırlamadoğrultusunda şekillendirmektedirler. Gelecekte karşılaşılabilecek olumlu ya da olumsuz ihtimaller ve süreçler hakkında yeni fikirler ortaya koyarak, bu süreç içerisinde gerekli gördüğünde büyük ve cesaret gerektiren projeler üretip uygulamaya koymaktan çekinmezler.

Bulut ve Uygun (2010)'un ifade ettiği gibi vizyoner liderlik anlayışı, liderin başında olduğu kurumu, proaktif (öngörüsel) ve insancıl bir yaklaşım ile öngörülen gerçekçi bir hedef doğrultusunda, hizmet verdiği kimselerin (müşteriler, vatandaşlar) beklentilerini temel alarak idare etmesine ve sürekli gelişme içinde tutmasına dayanmaktadır. Vizyoner liderler, işletmeyi başarıya ulaştırabilecek olan yolda geleceğin resmini çalışanlarıyla birlikte hareket ederek oluşturan, onlarla birlikte emek harcayan, yüksek motivasyon oluşturma yeteneği sayesinde çalışanlarını en iyi performans seviyesine çıkaran, güçlü örgüt kültürü oluşturarak bunu örgüt geneline yayan, bütün bunları hayata geçirirken gereken değişim ve gelişimin bilincinde olan kişilerdir.Vizyoner liderlerin bu yetenekleri, çevresel koşulları gözönünde tutarak, örgütün gelecekte ulaşmayı hedeflediği noktaya ulaşabilmesi için yeni strateji ve girişimler uygulamaya elverişli olacak şekilde örgütlerini çevik hale getirebilecektir.

Çeviklik, bir organizasyonun çevresindeki değişiklikleri (fırsatlar, tehditler veya ikisinin birleşimi) tespit etme ve müşterilerine, hissedarlarına kaynaklarını, süreçlerini ve stratejilerini yeniden düzenleyerek odaklanma ve bu duruma hızlı cevap verebilme yeteneğidir (Ganguly vd., 2009: 411).

Örgütsel çeviklik ise, bir organizasyonun yüksek kalitede ve etkin bir performans üreterek, hızlı ve istikrarlı bir şekilde değişen ve parçalara ayrılmış bir küresel piyasa ortamında rahatça çalışabilme kabiliyetidir. (Tsourveloudis ve Valavanis, 2002: 330). 
Bazı araştırmacılar örgütsel çeviklik kavramını etki alanı uygulamalarına ve bağlamlarına göre tanımlamaya çalışmışlardır. Örgütsel çevikliğin özelliklerini belirlemek için farklı kavramsal modeller önermişlerdir. Çevik bir örgütün temel boyutlarını, özelliklerini ve niteliklerini tanımlamak için bu önermelerin bazıları şu şekilde belirtilmiştir: Goldman ve arkadaşları (1995) örgütsel çevikliği, ürünlerden ziyade değer ve çözümler sunarak müşteriyi zenginleştirmek, rekabeti artırmak, işbirliğini hızlandırmak ve kullanılan kaynakları optimize etmek için işbirliği yapmak, insanı hızlı bir şekilde yeniden yapılandırarak ana değişikliklere alışmak, sahip olunan kaynak ve son olarak sürekli bir işgücü eğitimi ve örgütsel eğitim ile insanların ve bilgilerin etkisini arttırmak olarak boyutlandırmışlardır. Johansson (2003) çeviklik yeteneklerini dört ana boyuta ayırmışlardır; ürünle ilgili değişim yetenekleri, operasyonlardaki yetkinlik, iç ve dış işbirliği, insanlar, bilgi ve yaratıcılık. Sherehiy ve arkadaşları (2007), bir işletmenin tüm alanlarına uygulanabilen çevikliğin küresel özelliklerini esneklik, cevap verme, hız, değişim kültürü, bütünleşme ve düşük karmaşıklık, yüksek kalite, kişiselleştirilmiş ürün ve öz yetenekleri harekete geçirme olarak ifade etmişlerdir. Jackson ve Diğer yandan Imreh ve Raisinghani (2011) tarafından dört çevik uygulama kategorisi önerilmiştir: müşterileri zenginleştirmek, değişim konusunda ustalaşmak, rekabette iş birliği yapmak ve kaynaklardan, özellikle insan kaynaklarından yaralanmak. Ancak, birçok araştırmaya temel oluşturmuş en iyi kavramsallaştırma Sharifi ve Zhang (1999) tarafından yapılmıştır. Sharifi ve Zhang yaptıkları çalışmalar sonucunda örgütsel çeviklik yeteneklerini cevap verme, yetkinlik, esneklik, hız yetenekleri olarak belirlemişlerdir. Cevap verme yeteneği, değişiklikleri tanıma, hızlı yanıtlama ve bunlardan yararlanma yeteneğini ifade eder. Akkaya ve Tabak (2018) tarafından yapılan çalışmada özetlendiği üzere, farklı çalışmalarda cevap verme yeteneğine ilişkin ortaya koyulan örnekler şu şekildedir: değişimlere tepki vermesi ve örgüt yapısına uyarlama, değişimleri iyileştirme, stratejik vizyon belirleme, sezme, algılama ve değişiklikleri tahmin etme yeteneği, fiyatlardaki değişikliklere tepki verebilmek için hızlı karar vermesi, müşterin ihtiyaçlarındaki değişimleri fark etmeye meyilli olması, periodik olarak ürünlerin takip edilmesi, dış çevredeki değişimlere karşı bölümler arasında düzenli görüşmeler yapılması, rakiplerin kampanyalarına hızlakarşılık verebilmesi ve hayata geçirmesi, işletmedekidepartmanlar arası aktivitelerin iyi idare edilmesi, müşterilerinşikayetlerinin dikkate alınması ve takip edilmesi, işletmedeki bölümlerde ürün değişikliklerini yönetmesi, üşteri tercih ve ihtiyaçlarına cevap verme, pazar ve işletme çerçevesindeki değişim ve eğilimlere cevap verme, sosyal ve çevresel konulara cevap verme, işletmenin hedef ve amaçlarını değişimlere karşı uyarlayabilmektir.Esneklik yeteneğini, firmaların sürdürülebilirliğinin ve gelişiminin hem organizasyon içerisindeki makine, ürün, insan ve yapılanma konularını hem de müşterilerin değişen taleplerine, iç ve dış çevrede gerçekleşen olaylara tepki vermedeki yetenek olarak ifade edebiliriz. Oosterhout ve arkadaşları (2007) hız kavramının örgütsel çevikliğin uygulanabilirliğinin kalbi olduğunu belirtmişlerdir. Sherehiy (2007) ise bu yeteneği hızlı öğrenme, mümkün olan en kısa sürede değişiklik yapabilme, ürün ve hizmet sunumlarındaki hız olarak açıklamıştır. Yetkinlik kavramı örgütsel çevikliğin son yeteneği olmakla beraber cevap verme, esneklik ve hız yeteneklerinin birlikte kullanılabilme potansiyelini ifade etmektedir. Teece ve arkadaşları (1997) yetkinlik kavramını işletmelerin değişen iç ve dış çevre koşullarına yönelik uyum sağlamak için mevcut olan yeteneklerini ve yeterliliklerini bu süreç çerçevesinde sürekli uyarlama, yenileme ve yeniden yapılandırma yeteneği olarak tanımlamışlardır.

\section{AMAÇ VE HIPOTEZLER}

Araştırmanın literatür bölümünde vizyoner liderin sahip olduğu yeteneklerle örgütsel çeviklik yetenekleri arasındaki bağlar göz önünde bulundurulduğunda, belirsizliklerle dolu çevrede faaliyetlerini sürdürmeye çalışan günümüz işletmeleri için dış çevredeki eğilimleri tespit edebilen ve örgütü bu eğilimlere hazırlayabilen vizyoner liderlik ile örgütsel çeviklik arasındaki bağlantıyı ortaya koymak ve anlamak oldukça önemlidir. Bu bağlamda bu araştırmanın üç temel amacı vardır: İlk olarak, betimleyici istatistikler doğrultusunda Beylikdüzü’ndeki hastanelerde görev yapan yöneticilerin vizyoner liderlik düzeyi ile hastanelerin örgütsel çeviklik düzeyini belirlemek; ardından vizyoner liderliğin örgütsel çeviklik üzerinde etkisi olup olmadığını incelemek, eğer var ise etki düzeyini tespit etmek; son olarak da vizyoner liderlik alt boyutlarının (vizyoner düşünce, eylem odaklı olma, geleceğin resmi, değişimlere açık olma) örgütsel çeviklik yetenekleri (hız, cevap verme, yetkinlik ve esneklik) üzerine etkilerini incelemektir. 
Şekil 1: Araştırma Modeli

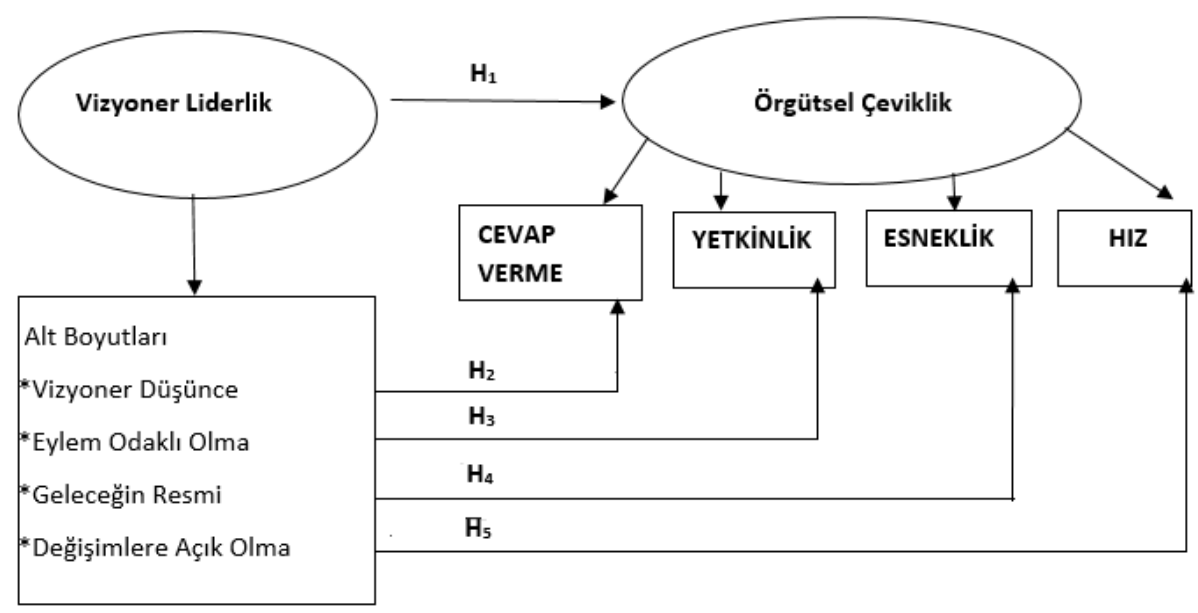

Şekil 1 bu çalışmada amaçlanan araştırma modelini sunmakta ve analiz edilecek alan amaçları ve hipotezleri özetlemektedir:

$\mathbf{H}_{1}$ : Vizyoner liderlik örgütsel çevikliği pozitif olarak etkilemektir.

$\mathbf{H}_{2}$ : Vizyoner liderliğin alt boyutları olan vizyoner düşünce, eylem odaklı olma, geleceğin resmi ve değişimlere açık olma örgütsel çevikliğin cevap verme boyutunu etkilemektedir.

$\mathbf{H}_{3}$ : Vizyoner liderliğin alt boyutları olan vizyoner düşünce, eylem odaklı olma, geleceğin resmi ve değişimlere açık olma örgütsel çevikliğin yetkinlik boyutunu etkilemektedir.

$\mathbf{H}_{4}$ : Vizyoner liderliğin alt boyutları olan vizyoner düşünce, eylem odaklı olma, geleceğin resmi ve değişimlere açık olma örgütsel çevikliğin esneklik boyutunu etkilemektedir.

$\mathbf{H}_{5}$ : Vizyoner liderliğin alt boyutları olan vizyoner düşünce, eylem odaklı olma, geleceğin resmi ve değişimlere açık olma örgütsel çevikliğin hız boyutunu etkilemektedir.

\section{ARAŞTIRMA YÖNTEMI}

\section{1. Örneklem}

Araştırmanın örneklemi, İstanbul ili Beylikdüzü ilçesindeki özel hastanelerden oluşmaktadır.Ülkenin içinde bulunduğu ekonomik ve siyasi koşullar, ülkedeki değişken sağlık uygulamaları, sağlık yönetmeliği ile ilgili yasaların sürekli değişmesi, hizmet sunumu kalitesinde malzeme ve ekipmanın yüksek teknoloji gerektirmesi ve bu teknolojinin yüksek maliyeti, nitelikli insan gücünün bölgeler, kurumlar ve hizmet alanlarındaki dengesiz dağılımı, rakiplerin sayısı ve sundukları hizmetler gibi iş çevresindeki belirsizlik ve karmaşa, bir çok sektörde olduğu gibi hastane işletmelerindeki başarısızlıkların nedeni olarak açıklanabilmektedir. Hastane işletmelerinde ortaya çıkabilecek bu başarısızlıklara dikkat çekmek, çözüm olarak da vizyoner lidelik ile örgütsel çevikliği önermek üzere bu örneklem seçilmiştir. Bu bölgedeki özel hastanelerde görev yapan doktor, hemşire, sağlık memuru, idari işler memuru ve diğer çalışanlardan veri toplayabilmek için amaçlı örnekleme kullanılmıştır. Beylikdüzü llçe Sağlık Müdürlüğü web sitesi incelenmiş ve bu ilçede faaliyet gösteren beş özel hastane görünmesine ragmen bunlardan üçünün büyük hastane olduğu tespit edilmiş ve bu hastaneler özenle seçilmiş yöneticiler tarafından stratejik olarak yönetilirler düşüncesinden yola çıkarak örnekleme dahil edilmiştir. Araştırmaya katılmaları için bu üç hastaneye eşit fırsat verilmiş, fakat hastanelerden biri, bir vakıf üniversitesiyle protokol imzaladıklarını, sadece oradan gelen araştırma taleplerini kabul edebildiklerini belirterek araştırmaya katılmayı reddetmiştir.

\subsection{Araştırmada Kullanılan Ölçekler}

Verilerin toplanması için ölçüm aracı olarak iki anket belirlenmiştir. Birinci anket Çınar ve Kaban (2012) tarafından geliştirilen Eranıl (2014) tarafından uygulanan Vizyoner Liderlik ölçeğidir. Bu ölçek çalışanların yöneticileri hakkında sahip oldukları vizyoner liderlik algılarını ölçmektedir. Söz konusu ölçek "vizyoner düşünce, eylem odaklı olma, geleceğin resmi ve değişimlere açık olma” olmak 
üzere 4 boyuttan ve 14 maddeden oluşmaktadır. İkinci anket ise, Sharifi ve Zhang (1999) tarafından geliştirilen, Akkaya ve Tabak (2018) tarafından da Türkçe'ye uyarlanan, güvenirliği ve geçerliği test edilmiş Örgütsel Çeviklik Ölçeğidir. Bu anket ise "yetkinlik, esneklik, cevap verme ve hız" olmak üzere 4 boyuttan ve 17 maddeden oluşmaktadır. Yapılan ankette her bir ifade için beşli derecelendirme (1. Kesinlikle katılmıyorum - 5. Kesinlikle katılıyorum) kullanılmıştır. Tüm değişkenler için güvenilirlik analizleri ve normallik testleri, bu çalışmada da yapılmıştır. Ölçeklerin güvenilirliğini test etmek için ise iki ölçeğin Cronbach Alfa ( $\alpha$ ) katsayıları hesaplanmıştır. Bu değerlerin her iki ölçek ve ölçeklere ait alt boyutlar için 0,70 'ten büyük çıkması, ölçeklerin güvenirliğinin yüksek olduğunu göstermektedir.

Tablo 1: Bağımlı ve Bağımsız Değişkenlere Genel Bakış

\begin{tabular}{|c|c|c|c|c|}
\hline \multicolumn{2}{|c|}{ Değişkenler/Boyutlar } & İfadeler & Ölçekler & Chronbach's alpha \\
\hline \multicolumn{2}{|c|}{ Vizyoner Liderlik } & 14 & Çınar ve Kaban (2012), Eranıl (2014) & 0.935 \\
\hline \multirow{4}{*}{ 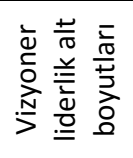 } & Vizyoner düşünce & 4 & & 0.910 \\
\hline & Eylem odaklılık & 4 & & 0.817 \\
\hline & Geleceğin resmi & 3 & & 0.841 \\
\hline & Değişimlere açıklık & 3 & & 0.826 \\
\hline \multicolumn{2}{|c|}{ Örgütsel Çeviklik } & 17 & Sharifi ve Zhang (1999), Akkaya ve Tabak (2018) & 0.930 \\
\hline \multirow{4}{*}{ 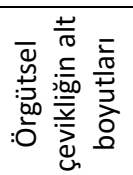 } & Yetkinlik & 8 & - & 0.825 \\
\hline & Esneklik & 3 & - & 0.827 \\
\hline & Cevap verme & 3 & - & 0.869 \\
\hline & $\mathrm{HIz}$ & 3 & & 0.887 \\
\hline
\end{tabular}

Veri toplamak için oluşturulan anket üç bölüme ayrılmıştır. Anketin birinci bölümde yer alan ifadelerle yaş, cinsiyet, hastanede çalışma yılı, pozisyon ve görev gibi katılımcılar hakkındaki genel bilgilere ulaşmak hedeflenmiştir. İkinci bölümde, 14 ifadeye yer verilmiş ve hastanedeki doktor, hemşire, sağlık memuru, idari işler memuru gibi çalışanların doğrudan yöneticileriyle ilgili algılarından yola çıkarak, hastane yöneticilerinin vizyoner liderlik özellikleri ölçülmüştür. Üçüncü bölümde ise 17 ifade ile bu çalışanların örgütsel çeviklik algı düzeyleri ölçülmüştür. Tasarlanan anketin ikinci ve üçüncü bölümü için beşli derecelendirme (1. Kesinlikle katılmıyorum - 5. Kesinlikle katılıyorum) kullanılmıştır. Anketlerin doldurulmasını sağlamak üzere hastane yönetiminden izin ve randevu alınmış, analizler için uygun, tam olarak doldurulmuş 199 anket elde edilmiştir.

\section{BULGULAR}

Vizyoner liderlik ve örgütsel çeviklik arasındaki nedensel bağlantıyı görebilmek, vizyoner lideriğin her bir alt boyutunun örgütsel çevikliğin her bir alt boyutu üzerindeki açıklama güçlerini ortaya koymak amacıyla geliştirilen hipotezlerini test etmek üzere basit ve çoklu regresyon analizleri yapılmıştır. Analiz sonuçları aşağıdaki tablolarda gösterildiği gibidir.

Tablo 2: Örgütsel Çeviklik Hususunda Vizyoner Liderlik

\begin{tabular}{lccccc}
\hline Bağımsız Değişkenler & Beta & $\mathbf{R}^{2}$ & F-Test & t- value & p-value \\
\hline Vizyoner liderlik & .485 & .232 & 60.775 & 7.795 & .000 \\
\hline
\end{tabular}

Bağımlı Değişken: Örgütsel çeviklik

Tablo 2' deki $\mathrm{H}_{1}$ hipotezine ait regresyon sonuçları incelendiğinde, regresyon modeline ait $\mathrm{R}^{2}$ değerinin 0,232 olduğu görülmektedir. Bu da vizyoner liderlik değişkeninin, örgütsel çeviklik durumundaki değişimin \%23.2'sini açıkladığı anlamına gelmektedir. Vizyoner liderliğin örgütsel çeviklik üzerindeki etkisi pozitif yönde ve anlamlıdır $(\beta=0,485 ; p<, 001)$.

Tablo 3: Yetkinlik Hususunda Vizyoner Düşünce, Değişimlere Açık Olma, Eylem Odaklılık ve Geleceğin Resmi

\begin{tabular}{llll}
\hline Bağımlı Değişken & Yetkinlik & & \\
\hline Bağımsız Değişken & Beta $(\boldsymbol{\beta})$ & t değeri & t değerinin anlamlılık düzeyi \\
\hline Vizyoner Düşünce & .114 & 1.320 & .189 \\
\hline Değişimlere Açık Olma & $.222^{* *}$ & 2.641 & .009 \\
\hline Eylem Odaklıık & $.318^{* *}$ & 3.773 & .000 \\
\hline Geleceğin Resmi & .040 & .391 & .697 \\
\hline
\end{tabular}




\begin{tabular}{ll}
\hline $\mathbf{R}^{2}$ & .238 \\
\hline $\mathrm{F}$ & 31.972 \\
\hline F değerinin anlamlılık düzeyi & .000 \\
\hline
\end{tabular}

${ }^{* *}: .01$ düzeyinde anlamlıdır.

Tablo 3' deki R² değeri, bağımlı değişkenin (yetkinlik) ne kadarının bağımsız değişkenler (vizyoner düşünce, değişimlere açık olma, eylem odaklı, geleceğin resmi)tarafından açıklandığını göstermektedir. Buna göre yetkinlikteki değişimin \% 23.8'lik kısmı vizyoner liderliğin alt boyutları olan değişimlere açık olma ve eylem odaklılık tarafından açıklanabilmektedir. Bu boyutların yetkinlik üzerindeki etkisi pozitif ve anlamlıdır $(\beta=0.222, p<.001 ; \beta=0.318 ; p<.001)$. Vizyoner düşünce ile geleceğin resmi boyutlarının yetkinlik üzerindeki etkisi istatistiksel olarak anlamlı olmadığından, program tarafından model dışında tutulmuştur ( $p>.05)$.

Tablo 4: Esneklik hususnda vizyoner düşünce, değişimlere açık olma, eylem odaklılık ve geleceğin resmi

\begin{tabular}{llll}
\hline Bağımlı Değişken & Esneklik & & \\
\hline Bağımsız Değişken & Beta $(\boldsymbol{\beta})$ & $\mathbf{t}$ değeri & t değerinin anlamlılık düzeyi \\
\hline Vizyoner Düşünce & .114 & 1.341 & .182 \\
\hline Değişimlere Açık Olma & .041 & .458 & .648 \\
\hline Eylem Odaklılı & $.380^{* *}$ & 5.758 & .000 \\
\hline Geleceğin Resmi & .092 & .972 & .332 \\
\cline { 1 - 2 } $\mathbf{R}^{\mathbf{2}}$ & .140 & & \\
\cline { 1 - 2 } & 33.155 & & \\
\cline { 1 - 2 } $\mathbf{F}$ değerinin anlamlılık düzeyi & .000 & & \\
\cline { 1 - 2 }
\end{tabular}

${ }^{* *}: .01$ düzeyinde anlamlıdır.

Tablo 4' teki R² değeri .140 olarak bulunmuştur. Buna göre esneklikteki değişimin \% 14'lük kısmı vizyoner liderliğin alt boyutu olan eylem odaklılık tarafından açıklanabilmektedir. Bu boyutun esneklik üzerindeki etkisi pozitif ve anlamlıdır $(\beta=0.380, p<.001)$. Vizyoner düşünce, değişimlere açık olma ile geleceğin resmi boyutlarının esneklik üzerindeki etkisi istatistiksel olarak anlamlı olmadığından, program tarafından model dışında tutulmuştur ( $p>05)$.

Tablo 5: Cevap verme hususnda vizyoner düşünce, değişimlere açık olma, eylem odaklılık ve geleceğin resmi

\begin{tabular}{llll}
\hline Bağımlı Değişken & Cevap verme & & \\
\hline Bağımsız Değişken & Beta $(\boldsymbol{\beta})$ & t değeri & t değerinin anlamlılık düzeyi \\
\hline Vizyoner Düşünce & .140 & 1.763 & .080 \\
\hline Değişimlere Açık Olma & .096 & .974 & .331 \\
\hline Eylem Odaklılı & .125 & 1.303 & .194 \\
\hline Geleceğin Resmi & $.346^{* *}$ & 5.184 & .000 \\
\hline $\mathbf{R}^{2}$ & .116 & & \\
\cline { 1 - 2 } & 26.872 & & \\
\cline { 1 - 2 } F değerinin anlamlılık düzeyi & .000 & & \\
\hline
\end{tabular}

${ }^{* *}: .01$ düzeyinde anlamlıdır.

Tablo $5^{\prime}$ teki çoklu regresyon modeli için $\mathrm{R}^{2}$ değeri .116 olarak bulunmuştur. Buna göre, örgütsel çevikliğin cevap verme boyutundaki değişimin \% 11.6'lık kısmı vizyoner liderliğin alt boyutu olan geleceğin resmi tarafından açıklanabilmektedir. Bu boyutun cevap verme üzerindeki etkisi pozitif ve anlamlıdır ( $\beta=0.346, p<.001)$. Vizyoner düşünce, değişimlere açık olma ile eylem odaklııık boyutlarının cevap verme üzerindeki etkisi istatistiksel olarak anlamlı olmadığından, program tarafından model dışında tutulmuştur ( $p>05)$.

Tablo 6: Hız hususnda vizyoner düşünce, değişimlere açık olma, eylem odaklııı ve geleceğin resmi

\begin{tabular}{llll}
\hline Bağımlı Değişken & Hız & & \\
\hline Bağımsız Değişken & Beta $(\boldsymbol{\beta})$ & t değeri & t değerinin anlamlılık düzeyi \\
\hline Vizyoner Düşünce & .163 & 1.928 & .055 \\
\hline Değişimlere Açık Olma & .043 & .483 & .629 \\
\hline Eylem Odaklılık & $.389^{* *}$ & 5.922 & .000 \\
\hline
\end{tabular}




\begin{tabular}{llll}
\hline Geleceğin Resmi & .103 & 1.094 & .275 \\
\cline { 1 - 2 } $\mathbf{R}^{\mathbf{2}}$ & .147 & & \\
\cline { 1 - 2 } & 35.066 & & \\
\cline { 1 - 2 } $\mathbf{F}$ değerinin anlamlılık düzeyi & .000 & \\
\hline
\end{tabular}

${ }^{* *}: .01$ düzeyinde anlamlıdır.

Tablo 6' daki regresyon modeli için $\mathrm{R}^{2}$ değeri .147 olarak bulunmuştur. Buna göre, örgütsel çevikliğin hız boyutundaki değişimin \% 14.7' lik kısmı vizyoner liderliğin alt boyutu olan eylem odaklılık tarafından açıklanabilmektedir. Bu boyutun hız üzerindeki etkisi pozitif ve anlamlıdır $(\beta=0.389, p<.001)$. Vizyoner düşünce, değişimlere açık olma ile geleceğin resmi boyutlarının hız üzerindeki etkisi istatistiksel olarak anlamlı olmadığından, program tarafından model dışında tutulmuştur ( $p>05$ ).

\section{SONUÇ, TARTIŞMA VE ÖNERILER}

Bu çalışmanın temel odak noktası, işletmelerin cevap verme, hız, esneklik ve yetkinlik gibi örgütsel çeviklik yeteneklerini edinmelerinde vizyoner liderliğin rolünü ortaya koymaktır. Yöneticilerin ve liderlerin vizyoner lider özelliklerine sahip olmalarının, işletmelerin çevresel ve içsel faktörlerde oluşan ani, öngörülemeyen değişikliklere hızla uyum sağlama, ortaya çıkan yeni gelişmeler doğrultusunda yeniden düzenlemeye giderek değişen çevre koşullarında hayatta kalma başarısı elde etme ve bunun yanı sıra karlılıkta sürekliliği sağlayabilme yetenekleri üzerindeki etkisinin hangi düzeyde olduğu sorusuyla yola çıkılan araştırma çerçevesinde farklı analiz yöntemleri uygulanmıştır. Analizlerden elde edilen neticeler ve bu neticelere ilişkin öneriler paragraflar halinde sıralanmıştır.

İstatistiksel analizlerde yer alan bulgulara göre, vizyoner liderlik örgütsel çevikliği etkilemektedir. Vizyoner liderler mevcut gerçeklikten yola çıkarak geleceğin gerçekliğini yakalama çabası içinde olurlar. Vizyon oluşturmakla kalmaz, değişimleri öngörürler, değişim süreci ve belirsizlikler içindeki örgütler için bir yol haritası olurlar. Çalışanları vizyon ve değişim çerçevesinde motive ederek işletme amaçlarına odaklanmalarını sağlarlar. Ayrıca örgütsel amaçlar için çalışanların beceri ve yeteneklerine odaklanarak gelişimlerine katkıda bulunurlar. İzlenecek yol, ulaşılacak hedefleri belirtir ve bunları çalışanlara açık, sözlü ve yazılı iletişim yoluyla aktarırlar. Böylece çalışanlar yaptıkları işin örgütsel amaçlar için anlamını ve katkılarını açıkça anlayabilir, lider tarafından yönlendirmelerle de kendisinden beklenilenlerin farkında olurlar. Bunların bir yansıması olarak örgüt, bütünüyle çevresel ve içsel faktörlerde oluşan ani, öngörülemeyen değişikliklere hızla uyum sağlayabilecek çevikliğe ulaşabilir.

Araştırmanın bir başka bulgusuna göre, vizyoner liderliğin alt boyutları olan değişimlere açık olma ve eylem odaklılık örgütsel çeviklik yeteneklerinden yetkinliği anlamlı olarak etkilemektedir. Bir taraftan gelecekte karşılaşılabilecek olumlu veya olumsuz durumları araştıran, diğer taraftan proaktif bir yaklaşımla öngörülen durumlar için gerçekçi hedefler belirleyen vizyoner liderler, mevcut olan yeteneklerini ve yeterliliklerini hizmet verdikleri kimselerin beklentilerini karşılamak üzere sürekli olarak uyarlayabilir, yenileyebilir ve yeniden yapılandırma yetkinliğini arttırabilirler.

Diğer bir bulguda ise vizyoner liderliğin alt boyutu olan eylem odaklılık, örgütsel çeviklik yeteneklerinden esnekliği anlamlı olarak etkilemektedir. Örgütün sahip olduğu vizyon dahilinde astlarına belirli sorumluklar yükleyen ve onları sürecin bir parçası kılan vizyoner liderler, sergilediği bu liderlik davranışı ile örgütün yapısını ileride meydana gelebilecek değişikliklere hazırlar.Bu sayede gerekli durumlarda örgütün kaynaklarını harekete geçirebilme kabiliyetine katkıda bulunurlar.

Vizyoner liderliğin alt boyutu olan geleceğin resmi ile örgütsel çevikliğin alt boyutu olan cevap verme yeteneği arasındaki ilişki pozitif ve anlamlı olarak bulunmuştur. Eğitimin gerekliliğine inanan ve sürekli öğrenmenin örgüt yapısına katacağı gücün bilincinde olan vizyoner liderler, bu düşünce yapısını astlarına da aktararak gelişmiş ve yeniliklere açık bir örgüt bilinci oluştururlar. Vizyoner liderlerin sahip oldukları bu görüş örgütlerin mevcut piyasa koşullarında rekabet edebilme gücü kazanmasına, değişimlere hazırlıklı olmasına ve bu değişimlere cevap verebilme yeteneğine katkı sağlar.

Vizyoner liderliğin alt boyutu olan eylem odaklılık ile örgütsel çevikliğin alt boyutu olan hız yeteneği arasındaki ilişki pozitif ve anlamlı olarak belirtilmiştir. Hizmet verdiği kimselerin beklentilerini temel alarak çalışmalarını sürdüren vizyoner liderler, örgütün rakiplerine kıyasla müşteri talep ve isteklerine daha kısa sürede cevap verebilmesini, ürün ve hizmetlerin hazırlanması sürecinde rakiplerine oranla daha hızlı olmasına katkı sağlar.

Yukarıda ifade edilen bağlantılar nedeniyle dış çevreye uyum sağlamak, rekabet edebilmek ve karlıı̆ı̆ sürdürebilmek isteyen işletmeler gerek yönetici seçiminde gerekse yönetici yetiştirme programlarında adayların vizyoner liderlik düzeyine odaklanmaları tavsiye edilebilir. Vizyoner liderlerin öncülüğünde hareket eden işletmelerin ise örgütsel çeviklik düzeylerini arttırarak piyasa hâkimiyetlerinde bir kayba uğramamaları, kar oranlarında düşüş yaşamamaları mümkündür. Literatür kısmında belirtilen örnek şirket hareketlerinde görüyoruz ki, dış çevrede meydana gelen olaylara göre örgüt içerisindeki mevcut yönetim şekli ve yöneticilerin sergilediği kısıtlı öngörü becerisi nedeniyle büyük şirketler kapanmaya gitmişlerdir. Diğer bir yandan ise dış çevreye 
duyarlı ve örgüt içerisindeki yapıyı daha önceden oluşabilecek durumlara hazırlayan yöneticiler sayesinde firmalar büyük başarılar elde etmiş ve günümüz piyasa koşullarında kendi alanlarında büyük payı ellerinde tutmaktadır. Bu örneklerden yola çıkarak söyleyebiliriz ki, örgütlerin çeviklik kazanmasının önemli yollarından biri yönetici seçiminde vizyoner liderlerin ön plana çıkarılmasıdır.

\section{REFERANSLAR}

Akkaya B. ve Tabak A.(2018) "Örgütsel Çeviklik Ölçeğinin Türkçeye Uyarlanması: Geçerlik ve Güvenirlik Çalışması". İş ve Insan Dergisi., 5 (2). 185206.

Bulut Y. B. Ve Uygun S. (2010) "Etkin bir yönetim için vizyoner liderliğin önemi: Hatay'daki kamu kurumları üzerinde bir uygulama" Importance Of Vısıonary Leadershıp For An Actıve Admınıstratıon: An Applıcaton In Publıc Instıtutıons In Hatay." Mustafa Kemal Üniversitesi Sosyal Bilimler Enstitüsü Dergisi, 7.13, s. 29-47.

Çınar, F. ve Kaban A. (2012) “Conflict Management and Visionary Leadership: An Application in Hospital Organizations." Procedia - Social and Behavioral Sciences, 58 (1), (197-206)

Crosby B. C. (1999) "Leadership for global citizenship: Building transnational community."Sage Publications, s.107

Eranıl, A. K. (2014) “Mesleki ortaöğretim kurumlarında görev yapan yöneticilerin vizyoner liderlik özellikleri ile öğretmenlerin iş doyumu düzeyleri arasındaki ilişki." Gaziosmanpaşa Üniversitesi, (Yayımlanmamış Yüksek Lisans Tezi).

Ganguly A. v.d. (2009) "Evaluating agility in corporate enterprises." International Journal of Production Economics, 118.2 ,s. $410-423$.

Goldman S. L. v.d. (1995) “Agile Competitors and Virtual Organizations: Strategies for Enriching the Customer”, Long Range Plann. vol. 29, s.131 Graetz, F. (2000). Strategic change leadership. Management Decision. 38/8. 550-562.

Imreh R. ve Raisinghani M. (2011) "Impact of agile software development on quality within information technologyorganizations", Journal of Emerging Trends in Computing and Information Science, 2.10, s.460-475.

Jackson M ve Johansson C. (2003), "An agility analysis from a production system perspective", Integrated Manufacturing Systems, 14.6, s. 482488.

Koçel T. (2001). "İ̧̧letme Yöneticiliği: Yönetim ve Organizasyon. Organizasyonlarda Davranış, Klasik-Modern-Çağdaş Yaklaşımlar", İstanbul: Beta Basım Yayım, s.400

Oosterhout M. V. v.d. (2007) "Business Agility: Need, Readiness and Alignment with IT Strategies Agile Information Systems:

Conceptualization", Construction and Management, Vol. 44, s. 52-69.

Quigley J. V. (1998) "Vizyon Oluşturulması, Geliştirilmesi ve Korunması", Çev: Berat Çelik, 1. Baskı, İstanbul, Epsilon Yayıncılık,

Robbins S. P. (2000) "Essentials of Organizational Behavior", New Jersey, PrenticeHall, Upper Saddle River, s.245

Sharifi H ve Zhang Z. (1999) "A methodology for achieving agility in manufacturing organisations: An introduction", International journal of production economics, 62.1-2, s.7-22.

Sherehiy B. v.d. (2007) "A review of enterprise agility: Concepts, frameworks, and attributes", International Journal of industrial ergonomics, 37.5 s.445-460.

Şimşek M. Ş. V.d. (2001) “Davranış Bilimlerine Giriş ve Örgütlerde Davranış”, Nobel Yayın Dağıtım, 2. Baskı, Ankara.

Teece D.J. v.d. (1997), "Dynamic capabilities and strategic management." Strategic management journal, 18.7, s. 509-533.

Tekin Y. ve Ehtiyar R, (2011) “Başarının Temel Aktörleri: Vizyoner Liderler”, Journal of Yasar University, 24(6), s. 4007-4023.

Tengilimioğlu D. (2005) “Kamu ve Özel Sektör Örgütlerinde Liderlik Davranışı Özelliklerinin Belirlenmesine Yonelik Bir Alan Çalısması”, Elekrtonik Sosyal Bilimler Dergisi, Sayı.14, s.1-16, https://dergipark.org.tr/tr/download/article-file/69862 (Erişim Tarihi: 08.04.2019)

Tsourveloudis N. C. ve Valavanis K. P. (2002) "On the measurement of enterprise agility." Journal of Intelligent and Robotic Systems, 33.3, s. 329342

Yukı, G. (2018). Örgütlerde Liderlik. Çeviri Editörleri: Şahin Çetin-Resul Baltacı. 8. Basımdan Çeviri. Nobel Yayıncılık, Ankara

Zaccaro S. (2001) "The nature of executive leadership: A conceptual and empirical analysis of success" American Psychological Association 


\section{Ek A: Araştırmada Kullanılan Ölçekler}

\begin{tabular}{|c|c|}
\hline & Vizyoner Liderlik ölçeği \\
\hline \multirow{4}{*}{ 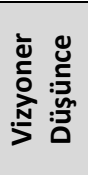 } & Çalışma grubunun dışında bağlantılar kurar ve bizlere güvenir, bizi ekip arkadaşı olarak görür. \\
\hline & Düşünmeyi teşvik edici tartışmalar açar. \\
\hline & Sürekli yeni fikirler üretir. \\
\hline & Durumları analiz eder. \\
\hline \multirow{4}{*}{ 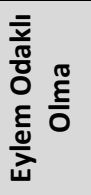 } & Sorunlara pratik çözümler bulur. \\
\hline & Hem yurtiçinde hem de yurt dışında faaliyet gösterme eğilimdedir. \\
\hline & İşini kurumun değerleri doğrultusunda yönetir. \\
\hline & Zamanlama kabiliyeti yüksektir. \\
\hline \multirow{3}{*}{ 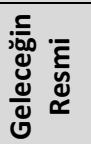 } & Büyük ve cüretkar projeler üretip uygular. \\
\hline & Günlük işler ile uğraşmak yerine kurumu geleceğe hazırlar. \\
\hline & Gelecekteki ihtimaller hakkında fikirler ortaya koyar. \\
\hline \multirow{3}{*}{ 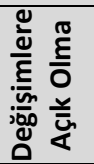 } & Değişime açıktır. \\
\hline & Öğrenme ve öğrendiklerini hastanede uygulama yeteneğine sahiptir. \\
\hline & Radikal kararlar almaktan çekinmez. \\
\hline
\end{tabular}

\begin{tabular}{|c|c|}
\hline & Örgütsel Çeviklik Ölçeği \\
\hline \multirow{8}{*}{ 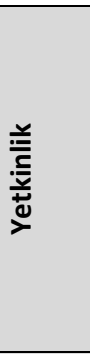 } & Hastanemiz uzun vadeli hedeflerini gerçekleştirecek stratejik vizyon ve hedeflere sahiptir. \\
\hline & Hastanemiz çağın gereklerine uygun miktarda ve yeterli teknolojiye sahiptir. \\
\hline & Hastanemiz, ürünleri ve bu ürüne ilişkin hastaya sunduğu hizmet kalitesi yüksektir. \\
\hline & Hastanemiz hedefine ulaşmak için tüm süreçlerde az maliyet ile çok kar elde etmeyi amaçlar. \\
\hline & Hastanemiz yüksek düzeyde reklam ve sağlık tanıtımı yapar. \\
\hline & Hastanemiz konusunda uzman ve yetkilendirilmiş insan kaynağına sahiptir. \\
\hline & Hastanemiz tüm kurum hiyerarşi, yönetim kademelerini basit, açık ve net tanımlamıştır. \\
\hline & Hastanemiz, kurum içi ve kurum dışında iş birliği ortamı sağlamaya ve geliştirmeye önem verir. \\
\hline \multirow{3}{*}{ 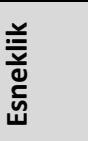 } & Hastanemiz, farklı departmanlarda hastalara hizmet sunma esnekliğine sahiptir. \\
\hline & Hastanemiz, bir çok farklı alanda hizmet üretme esnekliğine sahiptir. \\
\hline & Hastanemiz insan kaynakları politikaları kapsamında esnekliğe sahiptir. \\
\hline \multirow{3}{*}{ 造 巳 } & Hastanemiz, hastaların ihtiyaçlarındaki ve tercihlerindeki değişiklere hızla cevap verme yeteneğine sahiptir. \\
\hline & Hastanemiz çevresel değişiklikleri hisseder, algılar ve bu değişimlere hazırlıklı olur. \\
\hline & Hastanemiz yeniliklere ve çevre, teknoloji kaynaklı değişiklikleri hızla adapte yeteneği rakiplerine göre yüksektir. \\
\hline \multirow{3}{*}{$\stackrel{\underline{N}}{\underline{x}}$} & Hastanemiz hastalara hizmet sunma konusunda rakiplerine oranla daha hızlıdır. \\
\hline & Hastanemiz, yeni çıkan ürünleri hastanede kullanma konusunda hızlıdır. \\
\hline & Hastanemiz hastalara hızlı ve zamanında tetkik ve tedavi hizmetini sunar. \\
\hline
\end{tabular}

